\title{
The Role of Competition Law in Regulatory European Private Law
}

\author{
Armin Lambertz
}

\section{Introduction}

In the last years we have seen the emergence of a new methodology in European private law, which (finally) dared to shift away from a classical comparative approach to one, which takes European Union law as its proper starting point.' Classical European private law scholarship has mainly been backwards looking insofar as the law of the Member States, and predominantly the old codifications, determined both form and substance of new regulatory attempts. Today, this traditional approach still remains the predominant working method of the acquis group. ${ }^{2}$ But recent improvements in the academic debate surrounding European private law suggest a more European approach to questions of harmonisation. Taking the Treaties, secondary legislation and jurisprudence of the ECJ as its premise, academics have attempted to extrapolate common 'European' principles and rules to provide desperately needed substance in the search for more coherence in the continuing harmonisation process of private law. ${ }^{3}$ Some characteristics should be stressed as far as this new scholarship is concerned. First, it is heavily influenced by an idea which can be called 'Europeanisation of law through hybridisation of remedies'.4 Second, the methodology and reasoning on which this scholarship relies can only be explained on the basis of the European Economic Constitution. Alongside these main aspects we also find a more functionalistic approach as to how modern private law should be shaped in general. ${ }^{5}$ Last, new forms of governance allow for more flexibility in the law-making process, also in view of the actors involved in that process. ${ }^{6}$

\footnotetext{
1 Mak 2009.

2 On the reasons for this, see e.g.: Micklitz 2008, p. 4.

3 On the general principles of EU law, see e.g.: Tridimas 2006.

4 Reich 2007.

5 Micklitz 2008.

6 Ibid.
} 
It is against this background that this contribution seeks to demonstrate in what way competition law can serve as a tool to directly or indirectly influence and regulate private law in the Member States; and, more generally, how it can further the Europeanisation of law. In terms of methodology, I mainly rely on the idea that developments in European private law can be explained by aid of those areas which lie at the periphery of classical private law but at the core of the law of the internal market. To this end, it is necessary to first and foremost understand when and how competition and private law interact in the Union. The aim is to identify both instances in which competition and private law overlap substantially and in what way they complement each other.

It is indeed true that competition law is sometimes understood as standing in contrast to regulation. ${ }^{7}$ This is not only so because it is very generic in nature, but because its main aim is the smooth operation of the market free from any encumbrances. Regulation, on the other hand, is rather seen as intentional and targeted intervention on the market to control and monitor the behaviour of its participants. Yet whether this claimed dichotomy should still be accepted is highly questionable. It will be seen below that European competition law is less generic than one might be inclined to think and that it can indeed serve as a regulatory tool to impact specific market players. Instead of merely setting a framework to ensure free competition, anti-trust law in the Union heavily influences private relationship between firms inter-se and with other individuals. It therefore provides a perfect example for the increasing amalgamation of public and private law; a development which can equally be observed in the area of contract. The connection between competition and contract law becomes even more visible in light of the modernisation of competition law and the possibility of private enforcement. Contractual disputes between undertakings can be decided on the basis of competition law in the sense that individual parties can derive rights from the core provisions such as Articles 101 and 102 TFEU. And although this in itself is nothing particularly new, this contribution seeks to show that there is a need to generally rethink the implications of such intertwinement.

I will pursue the following strategy for the rest of this paper: After elaborating on the new European private law scholarship and its consequences, I will provide a general comparison between the law of contract and competition. I then seek to demonstrate in how far the recent developments in competition policy have impacted the private law branch with special regard to the on-going debate about the modernisation of competition policy and

7 Maher 2004, p. 187 et seq. 
the block exemptions regulations. I then will attempt to demonstrate why new forms of governance - primarily self-regulation - can prove to be a viable tool in competition and contract law and in how far these new modes of law-making further blend their distinction. In my conclusion, I will summarise my findings as well as I will provide some examples of fields where comparable developments can be expected and where more research is needed.

\section{A New European Legal Discourse}

As stated above, there has been a welcome and probably overdue development in European law scholarship. Issues of private law are no longer considered through the lens of national laws but are rather approached with an increasingly European perspective. This is nothing else than a shift from bottom-up to top-down analysis and has thus led to a fundamental change in legal methodology. ${ }^{8}$ The reasons for this shift lie in the functional changes of private law as a result of the economisation of private law in Europe, and a better understanding of the influence of general principles of European Union law on private law. ${ }^{9}$ It therefore seems as if legal reality has moved on with a higher pace than the academic debate surrounding it.

I identify three main aspects or parameters by means of which this new European scholarship can be understood:

1. There is the realisation that Europeanisation of law is driven heavily by the hybridisation of remedies - a term which I allowed myself to lent from Reich. ${ }^{10}$ In the absence of any Union measures, Member States retain the right to shape and define the procedural devices with which individuals can effectuate their rights. Due to the primacy of EU law and the doctrine of direct effects this autonomy is however considerably restricted whenever such rights spring from the Union legal order. This restriction goes so far that certain authors have stopped speaking of procedural autonomy of Member States, but merely of procedural competence." That is to say, Member States enjoy a certain discretion as to the form of remedies which enable persons to rely on their EU rights, but the protection afforded must always be adequate. Where national remedies fail to provide

8 See e.g.: Mak 2009.

9 Micklitz 2008, p. 47.

10 Reich 2007; see also: Collins 2011.

11 See e.g.: Van Gerven 2007, p. 502. 
such adequate protection, national courts need to adapt the law in order to live up to the doctrine of primacy and direct effects. ${ }^{12}$ This is what the principles of effectiveness and equivalence are all about. ${ }^{3}$

2. Europeanisation of law through hybridisation of remedies is complemented by what can be called the economisation of law. ${ }^{14}$ European private law not only pursues the purpose of defining the relationship between individual parties, but is equally understood as a regulatory tool to complete the internal market. ${ }^{15}$ Consumer law probably constitutes the most obvious example. The entire consumer acquis finds its raison d'être not so much in the protection it affords, but in the necessity to have such protection in order to strengthen consumer confidence and thereby enhance intra-Union trade. Consumer law - or European private law in general - is therefore in as much a branch of economic law as the laws of the four freedoms and competition are. ${ }^{16}$ At the end of the day, all these branches seek to enhance economic efficiency and to increase overall (or social?) welfare. The economisation of law is also very much visible in the way secondary legislation is enacted. The Commission seeks support for proposing new legislation primarily through its Impact Assessments which are meant to reveal differences in the laws of the Member States which have adverse effects on trade. ${ }^{17}$ To put it in the words of Cruz: "[...] the objective becomes more important than the norm"..$^{8}$ Competition law did not remain untouched by this development as the modernisation process which it has undergone since the millennium essentially boils down to a new economic approach to antitrust cases. ${ }^{19}$ Identifying these common denominators allows for a more informed discussion on how the core areas of the European Economic Constitution - the four freedoms and competition law - influence European private Law.

3. Finally, there is a more contentious claim which surrounds the debate. Few academics - but all of them with great assertion - have pointed to the relationship between new forms of governances and European private Law. New forms of law-making procedures

\footnotetext{
12 Reich 2007, p.708.

13 For a more general account, see e.g.: Tridimas 2006.

14 See e.g.: Kelemen 2011, p. 21 et seq (Chapter on 'The Political Economy of Eurolegalism').

15 Micklitz 2008, p. 6.

16 Arguably, it can even be considered as constituting one source for the European Economic Constitution; See for a different view: Cruz 2002, p. 3 et seq; compare also: Joerges 2000, p. 56 et seq.

17 Impact Assessment Guidelines, SEC(2009) 92.

18 Cruz 2002, p. 66.

19 See section 5 in this contribution on 'The impact of the Block Exemption Regulations'.
} 
combined with greater involvement of a variety of actors and stakeholders continue to shape the developments of law and regulation in the Union. ${ }^{20}$ Especially Micklitz, who seems to be on the forefront of this discourse, has argued that through the reliance on new regulatory instruments and enforcement mechanisms, the substance of (private) law itself is altered. ${ }^{21}$ For the purpose of this contribution, the possibility of having selfregulation in the field of competition in the future will be discussed below. But also the facilitation of private enforcement in competition cases plays an important role in this respect. On the whole, this discussion also relates to the idea that law loses its status as the catalyst of European integration, for it is substituted by an increasingly politicised process which manifests itself in those new forms and modes of governance..$^{22}$

All three parameters are necessary to discuss the potential impact of competition law on European private Law and throughout this contribution direct or indirect reference will be made to them.

\section{Contract and Competition Law}

As Schurr rightly observes: "Competition law deals with the relationship between private persons. Therefore it needs to be appreciated as a fundamental driving force in the process of Europeanisation of private law". ${ }^{23}$ Both Article 101 and 102 TFEU, being the core provisions of EU competition law, should be deemed relevant in the discussion on the future of European private law. The former prohibits inter alia anti-competitive agreements which are liable to distort trade, whereas the latter outlaws forms of abusive practices (including the imposition of unfair contractual terms) of dominant undertakings. The rules of competition therefore interfere with the contract-forming process of individual firms.

\subsection{The Narrow Perspective}

Notwithstanding such intertwinement, the law of contract and competition have originally been treated as utterly distinct from each other. ${ }^{24}$ Whereas the rules of contract regulate the legal relations between parties, the rules of antitrust were seen as primarily being concerned with the external effects of such relations. In this sense, the latter (in

\footnotetext{
20 See e.g.: Van Gerven 2006; Wouters 2012.

21 Micklitz 2008, p. 13. 
conjunction with general rules of public policy) define the framework within which private parties are free to determine the form and substance of their transactions. Both branches are heavily influenced by considerations of efficiency, albeit in different ways. Contract law seeks to minimize transaction costs by providing parties with the necessary tools to establish their respective rights and obligations vis-à-vis each other. Where problems arise, it additionally provides for the necessary remedies to mitigate the damage of failed transactions. ${ }^{25}$ Competition law, on the other hand, is first and foremost aimed at generating and preserving a level playing field for market participants. ${ }^{26}$ The efficiency of transactions is not assessed from the perspective of the parties in question but from the market as a whole. ${ }^{27}$ Since certain types of private agreements threaten to jeopardise third parties, it sets in place external constraints on such transactions. As a result, competition law is by its very definition at constant odds with the principle of freedom of contract. ${ }^{28}$ This tension became, for instance, apparent in the Bronner ${ }^{29}$ case where the ECJ was asked a question relating to a refusal by an Austrian newspaper to grant a competitor access to its nationwide delivery scheme. Having analysed the laws of the Member States, AG Jacobs held that the freedom of contract constitutes an essential element of free trade and that a careful balancing will always be required before competition policy should override this freedom..$^{30}$

Even under this more 'classical' view of the two branches of law, this tension can however be brought in a different perspective. Every balancing between the freedom of contract and the freedom to compete has to be understood in light of the more general concept of economic freedom. ${ }^{31}$ In a way, competition and contract law "are [...] the macro

25 Cseres 2010, p. 207

26 As a result, competition law equally preserves the foundations of our liberal democracy by preventing the creation of excessive private power. See e.g.: Amato 1997, p. 2 et seq.

27 Evans \& Quigley 2000, p. 82.

28 Cseres 2010, p. 208; for a French perspective on the matter, see e.g.: Dreifuss-Netter 1990.

29 C-7/97 Oscar Bronner GmbH \& Co. KG v. Mediaprint Zeitungs- und Zeitschriftenverlag GmbH \& Co. KG, Mediapring Zeitungsvertriebsgesellschaft mbH \& Co. KG \& Mediaprint Anzeigengesellschaft mbH \& Co. KG [1998] ECR I-07791. Opinion of Mr Advocate General Jacobs in C-7/97 Oscar Bronner GmbH \& Co. KG v. Mediaprint Zeitungsund Zeitschriftenverlag $\mathrm{GmbH} \&$ Co. KG, Mediapring Zeitungsvertriebsgesellschaft mbH \& Co. KG \& Mediaprint Anzeigengesellschaft mbH \& Co. KG [1998] ECR I-07791, at 53.

31 Some authors have criticised the fact that EU competition policy aims to protect economic freedom rather than competition itself. See e.g.: Wesseling 2000, p. 82 et seq. 
and micro levels of guaranteeing efficiency in the same continuum of market transactions".32 Efficiency arguments from both branches have to be taken into account in order to assess the intrusiveness of contractual constraints and their effects on private transactions. ${ }^{33}$ In some cases, contractual constraints can indeed result in efficiency gains not only for the individual firms but the economy as a whole. Competition law accepts these forms of collusion as long as the efficiency gains can be properly associated with the agreement in question.

\subsection{The Broader Perspective}

Seen this way, contract law provides mostly for enabling rules (i.e. enabling private parties to enter into transactions) whilst competition law is purely restrictive (i.e. by imposing external constraints). Yet this statement hardly provides the complete picture. It cannot be neglected that private parties to a transaction under scrutiny can equally derive rights from competition law and that these rights influence the outcome of contractual disputes. The possibility of private enforcement of antitrust breaches (see below) and the availability of substantive remedies in these cases - i.e. nullity, compensation, restitution and/or interim relief - alters the relationship between the two branches of law. ${ }^{34}$ According to Maher, competition law is "both a constraint on the freedom of contract and a device through which such freedom is protected [...]".35 By the same token, several substantive overlaps between the case law on Article 102 TFEU and the acquis communautaire of European private law can be observed. Although the overall aim of the Article remains the protection of competition by prohibiting abuses of a firm's dominant position, it is by its very definition targeted at situations involving an imbalance in bargaining powers. The protection of the weaker party therefore plays a pivotal role in the application of this provision; very much alike the general policy aim of many pieces of secondary legislation. ${ }^{36}$ In fact, European contract law - most notably in the area of consumer protection - is equally restrictive on the contractual freedom of parties in its attempt to mitigate the lack of bargaining power and information asymmetry.

Under the Directive on unfair terms in consumer contracts, for instance, a contractual clause which has not been individually negotiated and which runs counter the

\footnotetext{
32 Cseres 2010, p. 210.

33 For a comprehensive account on the matter, see e.g.: Steiner 2007

34 On the availability of remedies in Competition law cases: Van Gerven 2003.

35 Maher 2004, p. 205.

36 Schurr 2008, p. 13.
} 
requirement of good faith, will be deemed unfair where it leads to an imbalance in the rights and obligations of parties. ${ }^{37}$ As a result, the clause in question will not be binding on the consumer. ${ }^{38}$ Article 102 TFEU features remarkable similarities to this provision because it outlaws the imposition of supplementary obligations which are by their nature not connected to the subjected of the contract. ${ }^{39}$ Both rules therefore aim at preventing the exploitation of the weaker party and a cross-influence between them would be desirable.

Such cross-influence is particularly desirable given that both in contract (not only consumer law) and competition law the legal relevance of the concept of bargaining power is still a matter of controversy..$^{\circ}$ The law surrounding the abuse of superior bargaining power shows a great amount of divergence in the Member States, even in terms of classification. Whereas some enacted specific provision as part of national competition law (e.g. Germany), others regulate such abuses by means of their commercial law (e.g. France). The problem of classification mainly springs from the unavoidable interdependency between rules regulating unfair practices in competition versus rules against commercial practices that are restrictive for competition. ${ }^{41}$ The dividing line is thus supposed to be drawn according to the policy aim a given rule pursues. If it is aimed at the protection of competition, then it falls within the ambit of antitrust. Yet if it seeks to protect competitors, then it belongs to the area of unfair practices. This separation has also been included in Article 3(3) of Regulation 1/2003 which allows national regulators to implement rules which predominantly pursue other legitimate objectives than to protect competition. ${ }^{42}$ The exact meaning of this rather surprising restriction of Union control over competition is still open to debate. There is an inherent danger that national regulators qualify certain practices as unfair irrespective of their general effect on competition. The reservation contained Article 3(3) in favour of general principles and provisions of EU law will therefore hardly be sufficient to prevent protectionism (in fact, due to the principal of primacy it is in any case superfluous). ${ }^{43}$ Ullrich therefore suggests a redefined test in order to check the applicability of national rules. Instead of having regard to the overall objective of the rule, the question should be whether prohibiting a certain form

37 Article 3(1) Directive 93/13.

38 Article 6(1) Directive 93/13.

39 See sub-paragrpah (d) in Article 102 TFEU.

40

Cseres 2010, p. 214; see also: Schillig 2008.

41

Compare: Cseres 2010, p. 222.

42 Recital 9 to Regulation $1 / 2003$.

43

Ullrich 2005, p. 7 . 
of conduct can be justified even if it alters competition. This essentially boils down to a balancing between Union interests in free competition and national interests to maintain fair and honest competition. ${ }^{44}$ This is indeed preferable over a test which merely focuses on whether a certain norm attempts to regulate contractual relationships or competition as a whole. ${ }^{45}$ Only in this way can the effectiveness of EU competition law be maintained. It still remains to be seen how far the ECJ is willing to intervene in this matter.

The above-mentioned discussion might be seen either as an academic nightmare or a regulatory opportunity. As regards the latter, it reveals in how far the Commission is able to define the areas of contract law (or private law in general) which are still left for Member States to regulate. But it also shows that there needs to be (once again) a more informed discussion on what EU competition law actually seeks to protect - an issue which has never been properly solved. ${ }^{46}$ Whereas the Commission still takes up the cause of overall welfare maximisation, recent decisions such as Courage ${ }^{47}$ and Manfredi ${ }^{4}$ imply that also individuals - including competitors - can be protected by competition law. This, of course, begs the question how far Member States can in fact implement rules with other objectives in the area of unfair practices. After all, in the proposal for the long-awaited Directive on damages for antitrust breaches, Article 2 grants anyone who has suffered loss as a result of infringements of competition the right to compensation; and this can even include parties to an anti-competitive agreement itself as becomes apparent from case law. ${ }^{49}$ This aspect of competition law enforcement will be discussed more thoroughly below. For now it suffices to say that the mere fact that the Commission regards the ensuring of the victim's right to full compensation in competition law cases as one of the main objective of the Directive shows that this branch of law hugely influences private legal relationships..$^{50}$

\footnotetext{
44 Ullrich 2005, p. 8.

45 For a more thorough discussion, see: De Smijter \& Kjoelbye 1999.

46 On the aims of EU Competition law in general, see e.g.: Parret 2011, p. 111 et seq (Chapter on 'Shouldn't we know what we are protecting? Yes we should!').

47 C-453/99 Courage v. Crehan [2001] ECR I-6297; for an overview of the facts, see page 12.

48 C-295/04 to C-298/o4 Vincenzo Manfredi et al. v. Lloyd Adriatico Assicurazioni SpA [2006] ECR I-6297; for an overview of the facts, see page 13 .

49 Proposal for a Directive on certain rules governing actions for damages under national law for infringements of the competition law of the Member States and the European Union, COM(2013) 404 final; see also:C-453/99 Courage v. Crehan [2001] ECR I-6297.

50

$\operatorname{COM}(2013) 404$ final, p. 4.
} 


\subsection{The Notion of Fairness}

Last, there is another potential for cross-influence stemming from the case law on Article 102 TFEU in regards to the notion of fair pricing. Both in competition law and European private law instruments, courts are seized to assess the fairness and justifiability of prices between parties. In the famous United Brands case, the ECJ held that the imposition of prices, which show no reasonable relation to the economic value of what has been supplied will qualify as an abuse. ${ }^{51}$ A comparison can be made with Directive 86/653 for self-employed commercial agents. According to Article 6 of this Directive, a commercial agent is entitled to a remuneration, which corresponds to customary practice for the goods forming the subject of his or her agency in the absence of any specific agreement. Where no such customary practice is present, the agent shall be entitled to a reasonable remuneration. On the latter, the decision in United Brands and other cases on excessive pricing might prove influential, for in the past ways have been found to overcome the lack of comparable prices to make such assessment. ${ }^{52}$ Since the determination of prices is always an economically intricate undertaking, the underlying test has become increasingly sophisticated. Not only the overall costs plus profit margin are taken into consideration, but regard is also had to non-cost related factors and the particular circumstances of the case..$^{53}$ In view of the Agency Directive, the case law on Article 102 is particularly important because the ECJ has been concerned both with excessively high and low prices. Although the jurisprudence on too low prices on the purchasing side is by far not as rich as it is regarding high prices, there are certain indications that this will change in the future..$^{54} \mathrm{An}$ indication is provided by CICCE v. Commission which dealt with allegedly unfair low prices paid for broadcasting movies on French television..$^{55}$ Although the Commission rejected the complaint, it did not exclude the possibility that low prices can be regarded as an abuse under certain circumstances. Future developments in the ECJ's case law on this matter will certainly influence the understanding of fairness of prices in European private

51 C-27/76 United Brands v. Commission [1978] ECR 207, at 250.

52 See e.g.: Deutsch Post: Interception of Cross-Border Mail [2002] OJ L331/4O; see also: Albors-Llorens 2006, p. 262.

53 Jones \& Sufrin 2011, p. 535.

54 Especially large retail groups have become increasingly powerful and therefore subject to competition rules over the years. The Commission already pointed out in the mid-8os that as a result of improvements in marketing technique and network development, large distribution firms could increase their market shares and that competition policy should respond to this; see: XVIth Report on Competition Policy, Commission, Brussels 1986, at 345-348.

55 C-298/83 CICCE v. Commission [1985] ECR 1105. 
law as well. To give one further example why this will prove relevant, one merely needs to turn to the new Proposal for a Regulation on a Common European Sales Law. Article 51 of the Proposal integrates a provision on unfair exploitation which had already formed part of the DCFR (Article II. - 7:207). Exploitation is hereby understood as taking an excessive benefit or unfair advantage of the weaker party's position which will commonly manifest itself in a disparity in considerations. The economic analysis underlying the investigation of such disparity can indeed be facilitated by having regard to previous decision made in competition law cases.

Some might argue that allowing for an excessive intertwinement between the jurisprudence in competition law and the interpretation of private law instruments will lead to an undesirable mingling of actually distinct branches of law. ${ }^{56}$ However, it has to be stressed again that competition law in the European Union enjoys a genuine constitutional status and should therefore be allowed to exert an influence on all other areas. This indeed will lead to more coherence within the various branches themselves.

Above all, there should be the awareness that such influence exists in the first place. And this awareness is also ought to shape future developments in the area of competition law. The chance to attain more coherence can easily be wasted by not coordinating new reforms in the various branches. For instance, it would be highly advisable to provide for the same (or at least comparable) periods of time within which parties may seek avoidance.

\title{
4 The Characteristics and Effects of Decentralised Competition Law Enforcement
}

\begin{abstract}
"Modernisation of competition policy" is the terminology reserved to those reforms and developments which started briefly before the end of the millennium and which culminated in the enactment of Regulation 1/2003. The modernisation process had both a substantive and a procedural dimension, both being important in the discussion on the effects of competition law on European private law. On the whole, the following discussion particularly relates to the afore-mentioned new modes of governance and in how far they impact the private law branch. But it will equally become clear that hybridisation of remedies plays a substantial role in competition law cases.
\end{abstract}

56 Compare: Ullrich 2005, p. 45 et seq. 


\subsection{Regulation $1 / 2003$}

Procedurally speaking, Regulation 1/2003 set in place a new decentralised system of competition law enforcement. 57 This was done, firstly, by abolishing the former notification procedure under which undertakings or associations of undertakings could apply for negative clearance from the Commission..$^{58}$ Secondly, Articles 101 and 102 have been declared directly applicable, which for the first time includes the general exception provided for in Article 101(3), ${ }^{59}$ for both National Competition Authorities and national courts. Allowing for the direct applicability of the Articles in their entirety marked a drastic shift away from the old enforcement mechanism which had been purely administrative in nature and which mainly relied on an ex ante control in form of the notification procedure. Now, Regulation 1/2003 obliges national courts and authorities to apply EU competition law alongside national law whenever the case in question may have an effect on trade between Member States. ${ }^{60}$

These changes indeed seemed very appealing for the Member States insofar as they regained power and control over competition law cases. Yet as a matter of fact the reforms have been said to reinforce the dominant position of the Commission in the competition law framework rather than weaken it. ${ }^{61}$ What has occurred was a form of decentralisation without any devolution of powers. ${ }^{62}$ This is to say that National Competition Authorities and courts mainly carry out the workload of the Commission, while the latter remains dominant in determining the overall policy aims. ${ }^{63}$ Due to several duties imposed on National Competition Authorities, the Commission is always kept informed about current proceedings and retains the right to intervene at any stage which can even lead to a complete pre-emption of the national authority in specific cases. ${ }^{64}$

In a broader sense, the Regulation constitutes an interesting development in light of the procedural autonomy/competence of Member States as, throughout the instrument, rules can be found which touch upon the procedural law of national courts. Most notably,

57 This has been called the most significant reform in European Competition law, see e.g.: Ehlermann 2000, p. 537.

58 Article 2 Regulation $17 / 62$.

59 Before the enactment of Regulation $1 / 2003$, only the prohibitions contained in both Articles as well as the automatic voidness of agreements and decisions in Article 101(2) were directly applicable.

6o The same obligation is self-evidently imposed on National Competition Authorities, see: Article 3 Regulation $1 / 2003$.

61 Wilks 2005, p. 438; Riley 2003, p. 657.

62 Kelemen 2011, p. 169.

63 Ibid.

64 Articles $11-13$ Regulation 1/2003? 
Article 2 enshrines a general rule on the burden of proof in competition law cases imposing the onus on the party alleging the infringement. Although this rule is certainly based on the general principle of actori incumbit probatio ${ }^{65}$, it nonetheless constitutes a direct imposition of a procedural rule on national law. ${ }^{66}$ Likewise, Article 15 of the Regulation creates an amicus curiae ${ }^{67}$ system which allows both the Commission and National Competition Authorities to intervene in national proceedings. Such system is indeed new to most Member States. ${ }^{68}$ The most important provision in this respect, however, appears to be Article 16 which prohibits National Competition Authorities and national courts to take decisions which are contrary to a previous finding by the Commission on the same facts. Individual firms, irrespective of whether they were the offending or aggrieved party, can therefore derive rights from Commission decisions before national courts or against administrative proceedings by National Competition Authorities.

The only respect in which the Commission surrendered power relates to the promotion of private enforcement. Private enforcement of competition law cases in fact encompasses two ideas at the same time. ${ }^{69}$ On the one hand, as firms are unable to seek clearance in advance from the Commission, they have to analyse for themselves whether an agreement or specific market behaviour amount to a breach of competition rules. Such analysis then becomes an integral part of the negotiation process leading to any form of agreement between firms which inevitably impacts the private law branch. Especially smaller firms in weaker bargaining positions may use private enforcement as a tool to regain strength in the negotiation process thanks to the direct applicability of Articles $101 \& 102$ TFEU..$^{70}$ In this sense, the modernisation of competition law has to a certain degree privatised the process of regulation. ${ }^{11}$ On the other hand, the new enforcement regime is hoped to provide for more efficient detection of anticompetitive behaviour as other firms and consumers may initiate private actions against

65 Translates in: "The Claimant bears the burden of proof".

66 Parret 2011, p. 189

67 Translates in: "The friend of the Court". The concept enshrines the idea that the Commission can contribute to proceedings before national courts by providing information (relating to economic, factual and/or legal aspects) and by providing opinions on the application of the EU rules on competition to individual cases.

70 On a critical account of private enforcement in competition law, see e.g.: Wigger 2004. 
offenders. ${ }^{72}$ This can, of course, only be in the interest of the Commission itself.73

The (procedural) modernisation of competition policy can overall be seen as yet another example of the Commission to rethink the way in which regulation should take place in the Union. Decentralised enforcement generally plays an increasingly important role for the Union policy makers. ${ }^{74}$ To a certain extent, private actors are given the responsibility to ensure the functioning of the system.75

\subsection{Private Enforcement of Competition Law Cases}

It is worth dwelling a little bit longer on the last-mentioned aspect. Even though Regulation $1 / 2003$ pushed forward the 'privatisation' of enforcement, the possibility to rely directly on Article 101 or 102 has always been present. It nonetheless took remarkably long until a case was brought before the Court which properly tackled the question in how far parties to an allegedly anti-competitive agreement could derive rights from the core provisions of competition law. This case was Courage v. Crehan. ${ }^{76}$

Courage, a sizeable brewery holding, concluded a contract with a real estate company to merge their leased pubs while agreeing that all future tenants of those pubs were obliged to purchase their beer exclusively from Courage. When Crehan sought a lease, he was hence unable to negotiate all parts of the agreement. Whereas the rent itself was negotiable, the standard contract forced him to agree to the 'beer tie' which included a fixed minimum quantity of beers to be purchased within a given period of time. After not having paid for certain beer deliveries, Courage brought an action for recovery of almost 16.000 pounds. Before the court, Crehan contested inter alia the legality of the agreement because he noted that Courage sold its beer to considerably lower prices to independent tenants. He therefore not only asked for the annulment of the agreement but also sought damages for the price difference he had to pay.77 $\mathrm{A}$ problem arose insofar as English law - more precisely the principle of estoppel - barred a party to an illegal agreement to sue its co-contractor for damages. ${ }^{8}$ Faced with these issues, the Court of Appeal asked a preliminary question to the European Court on the legality of the principle of estoppel

\footnotetext{
72 Wigger 2007, p. 103.

73 Kelemen 2011, p. 171.

74 Kelemen 2011, p. 167.

75 Compare: Cafaggi \& Micklitz 2007.

76 Courage v. Crehan.

77 Courage v. Crehan, at 3-9.

78 Courage v. Crehan, at 11; See also: Albors-Llorens 2006, p. 265.
} 
under EU law in this specific case and on the possibility for an aggrieved party to an anticompetitive agreement to seek damages against the other contractor. ${ }^{79}$

The ECJ replied that the full effectiveness of EU competition law would be put at risk whenever an outright bar would be imposed on parties to a contract to seek damages for losses caused by the illegal agreement. ${ }^{80}$ National law can therefore not impose an absolute bar to such an action. ${ }^{81}$ Unlike its ruling in Francovich, the Court refrained, however, from introducing some general requirements under which a party may have the right to damages for antitrust breaches ${ }^{82}$ The wording of the judgement merely suggests that national courts should thoroughly investigate the respective bargaining positions and the conduct of the parties. This will prove helpful to determine whether or not the claimant has born 'significant responsibility' for the distortion of competition or whether the agreement was simply imposed. ${ }^{83}$

Making damages available to undertakings even though they form part of an illegal agreement renders private enforcement self-evidently more attractive. Yet next to these policy benefits, the introduction of substantive remedies - besides the action of nullity (Article 101(2) $)^{84}$ - alters the nature of litigation in those cases as well as the relationship between competition law and private law. ${ }^{85}$ In fact, the decision can justifiably be called a landmark decision in view of its impact on contractual and non-contractual private liability in the Member States. ${ }^{86}$ Although with some reluctance, I further wonder whether Crehan can be said to have introduced a general principle of protection of the weaker party in EU law. It is indeed remarkable that the policy arguments which the Court raises in favour of allowing for damages action follow the same mind-set the Commission follows in the consumer acquis; namely, to mitigate differences in bargaining powers by allowing for effective redress. ${ }^{87}$ It is all the more remarkable (and regrettable) that the Commission did

79 See for a case study focusing on the contract law aspects of the decision: Stuyck 2005; for an analysis of the consequences for tort actions, see: Reich 2005.

80 Courage v. Crehan, at 25.

81 Courage v. Crehan, at 28.

82 Albors-Llorens 2006, p. 266.

83 Courage v. Crehan, at 31-33.

84 See more generally on the interaction of EU and national law as far as voidness of anti-competitive agreements is concerned: Cauffmann 2013.

85 For an overview of the substantive remedies in Competition law cases, see once again: Van Gerven 2003.

86 Albors-Llorens 2006, p. 266.

87 On the relevance on effective redress in view of the economisation of private law: Micklitz 2008, p. 26. 
not seize the opportunity to further define the requirements under which a party to a tradedistorting agreement can seek damages in its recent proposal. This can definitely be seen as a missed chance to further define the interrelationship between competition and private law.

Private enforcement has also become increasingly attractive for aggrieved third parties. In Manfredi, a number of clients of Italian automotive insurers brought an action for damages on grounds that the premiums they had been charged were inflated by twenty per cent due to a prohibited collusion. ${ }^{88} \mathrm{After}$ reiterating that the full effectiveness of EU competition is only warranted when individuals can directly rely on it to find redress, the ECJ held that whenever there is a causal link between the prohibited agreement or practice and the harm suffered, compensation can be claimed. ${ }^{89}$ This general rule has now been incorporated in Article 2 of the Commission proposal. As this can include groups of consumers bringing a collective action against a cartel, the relation ship between consumer and competition law becomes even closer. The Commission took up this idea in its White Paper on Damages Actions for Breach of EC Antitrust Rules in which it addressed its plans to allow for representative actions (i.e. brought by qualified entities such as consumer associations) as well as opt-in collective actions (i.e. brought by a group of aggrieved individuals). ${ }^{\circ}$ However, the Proposal for a Directive on certain rules governing actions for damages under national law for infringements of the competition law of the Member States and the European Union does (unfortunately) not cover this aspect in its current form - probably due to some apprehension about the intrusiveness of such rules. Yet the proposal still covers general issues as to the access to evidence, limitation periods, passing-on defence, and the quantification of harm. ${ }^{91}$ Particularly the rules on disclosure are comparably detailed which once and for all puts into question the existence of what has been called procedural autonomy of Member States. The Directive, should it be adopted in the future, can therefore be said to be the first Union instrument which genuinely governs core elements of litigation outside the field of private international law. ${ }^{22}$

88 Vincenzo Manfredi et al. v. Lloyd Adriatico Assicurazioni SpA.

89 Vincenzo Manfredi et al. v. Lloyd Adriatico Assicurazioni SpA, at 6o-61.

90 White Paper on damages actions for breach of EC antitrust rules, COM(2008) 165 final, at 2.

91 The quantification of harm is indeed one of the most intricate problems in antitrust litigation. To this end, the Commission has issued two additional Communication (C(2013) 3440 \& SWD(2013) 205) alongside the proposal. While some leeway is given to Member States in terms of the standard of proof (see first document), the Commission provided a very complex 'Practical Guide' in which it sets out methods to quantify harm of specific anti-competitive practices (see second document).

92 This is not to say that are no procedural rules contained in other secondary legislation. For instance, The IP Directive 2004/48 already contains certain rules on disclosure of evidence. Yet in terms of scope the Directive on damages for antitrust breaches, at least as far as is predictable at the moment, surpasses all its predecessors. 
Even the Commission seems to acknowledge that these harmonising attempts, once put in practice, will open other doors for European private law. At almost the very end of its Staff Working Paper of 2008, it already points to the fact that some of the problems individuals and firms are facing in competition law cases also negatively affect other areas of civil/tort litigations. ${ }^{93}$ Rather hesitantly it therefore suggests that the proposed changes in private competition law enforcement could serve as a starting point for further convergence beyond antitrust damages actions. It remains to be seen what exactly the Commission has still up its sleeve. But regardless of any further harmonising attempts, the Directive on damages in antitrust cases may lead to spill-over effects which then automatically influence other areas of litigation as well.

\section{The Impact of the Block Exemption Regulations}

Substantially speaking, the modernisation process already began in 1999 and brought about a more economics based approach to competition law cases for both vertical and horizontal forms of collusion. ${ }^{94}$ In practice, this was achieved not only by means of several block exemption regulations, but also by new assessment criteria for anticompetitive conduct with a stronger focus on short term consumer welfare and proper economic analysis. ${ }^{95}$ The actual effect of agreements on the market has stood in the centre of the analysis ever since in lieu of a mere search for specific contractual clauses which were deemed trade-distorting outright. ${ }^{6}$ The rigorous economic approach to competition law cases goes hand in hand with its decentralised enforcement described above. Where enforcement is no longer driven by one central authority, objective microeconomic requirements are needed to assess anticompetitive conduct. Only this ensures that national authorities and courts apply the European rules on competition in a uniform and consistent manner. ${ }^{97}$

93 Commission Staff Working Paper accompanying the White Paper on damages actions for breach of the EC antitrust rules, SEC(2008) 404, at 312.

94 Commission Green Paper on Vertical Restraints in Competition Policy, COM(96) 721 final, at 54 et seq.; Guidelines on Vertical Restraints (2000/C 291/01), at 6 et seq. (OJEC 200 C 291); Guidelines on horizontal cooperation agreements (2001/C 3/02).

95 Wilks 2005, p. 113 et seq.

96 Vogelaar 2002, p. 21.

97 Kelemen 2011, p. 168-169. 
The objective criteria of assessment equally help firms to establish the legality of agreements they enter into. The Commission facilitated the process by issuing several new block exemptions of both general and specific application over the years. ${ }^{8}$ All these new Regulations mainly work on the basis of market power and the nature of the restraint. ${ }^{99}$ This has had several implications for European private Law. In practice parties have of course remained free to define their contractual terms, but the Block Exemption Regulations intervene indirectly in the contract formation process. Certain provisions are often literally copied (especially those relating to so-called hardcore restraints) to avoid prohibition. Some authors have even claimed that the new regime directly vested parties with certain rights. ${ }^{100}$ This belief was particularly tenacious regarding the former Block Exemption Regulation for motor vehicle distribution. ${ }^{101}$ Article 3 conditioned the application of the Regulation to the inclusion of certain contractual clauses such as the obligation for the supplier to give a written and reasoned notice for termination and a minimum duration of the distribution agreement. But what many apparently failed to see was that these conditions neither created rights for dealers, nor did they impose direct obligations on vehicle suppliers. ${ }^{102}$ They simply constituted the requirements which needed to be fulfilled by any distribution agreement in the car sector to benefit from the exemption..$^{103}$ No dealer could bring a legal action on the basis that a supplier refused to grant a contract which complied with the Regulation. ${ }^{104}$ Not only due to that controversy was the Regulation generally seen as a failure. ${ }^{105}$ In 2010, a new Block Exemption Regulation and guidelines for the motor vehicle sector has been issued which omits many of the controversial aspects of its predecessor and which mainly subjects agreements to

98 The most important Regulations on the application of Article 101(3) TFEU are the following: Regulation 330/2010 (the umbrella Regulation for vertical agreements); Regulation 461/2010 (vertical agreements and concerted practices in the motor vehicle sector); Regulation 1217/2010 (research and development agreements); Regulation 772/2004 (technology transfer agreements).

99 Cseres 2005, p. 127.

100 Micklitz 2008, p. 20.

101 Regulation 1400/2002.

102 Clark \& Simon 2010, p. 481.

103 This is exactly what the ECJ stated already in the mid-80s in a case that concerned the original Block Exemption Regulation for the motor vehicle sector (Regulation 123/85) in C-10/86 VAG France SA v. Etablissements Magne SA [1986] ECR I-4071.

104 This is not to say that there have not been cases on the matter: C-125/05 Vulcan Silkeborg A/S v. Skandinavisk Motor Co. A/S ECR 2006 I-07637; C-376/05 \& C-377/05 A. Brünsteiner GmbH \& Autohaus Hilgert GmbH v. Bayerische Motorenwerke AG (BMW) ECR 2006 I-11383.

105 Commission Memo/10/217 (Brussels, 27 May 2010). 
the conditions of the umbrella Regulation on vertical agreements with the addition of a sector specific list of prohibited hardcore restrictions. ${ }^{106}$

The way in which the Block Exemption Regulations on vertical agreements intervene in the contract-making process is indeed quite different. By imposing a mandatory framework on cartel agreements, they provide for more than simple affirmation or negation of the legality of a contract between firms. In this way, they have to be distinguished from the underlying prohibition contained in Article 101 (1) TFEU. Whenever firms enter into agreements which are liable to fall within the prohibition, they have little leeway in arranging their legal relationships. All they can do in practice is to align the contractual clauses with the provisions of the Block Exemption Regulations. ${ }^{107}$ These provisions are very detailed both in terms of the prohibited and allowed vertical restraints. Whenever firms seek to avail themselves of vertical integration to increase efficiency, they are hence very much restricted to the content of the Regulations. ${ }^{108}$ In a way, the Block Exemption Regulations work as a quasi-standardisation of cartel agreements. They are hard and soft law at the same time. It changes little in this respect that the validity of such agreements cannot be substituted by the Regulations insofar as they do not serve as model contracts or compel amendments to the original contract should it not be in accordance with the exemption requirements. ${ }^{109}$ Given this practical importance, the working of the Block Exemption Regulations should therefore be regarded as an integral part of European private Law.

\section{The Potential of Self-Regulation in Competition and European Contract Law}

The last major aspect which needs to be discussed is the so-far neglected possibility of fostering self-regulation in the area of competition law. For some, this statement in itself might cause some confusion, for usually competition law is seen as setting the limits for self-regulation, not a branch within which it can be of any use. ${ }^{10}$ Seeing, however, that

\footnotetext{
106 Regulation 461/2010.

107 Grundmann 1999, p. 913.

108 On the regulation of vertical agreements more generally: Wijckmans \& Tuytschaever 2011.

109 C-10/86 VAG France SA v. Etablissements Magne SA [1986] ECR I-4071, para. 12; Grundmann 1999, p. 913

110 On the Competition law limits to self-regulation: Dolmans 2002.
} 
competition law provides for contract standardisation through the Block Exemption Regulations, the potential of co-regulation in view of harmonising European contract Law (through competition law) in the form of contract standardisation should become apparent.

In an attempt to reduce the burden of regulation in the Union, the Commission has, among other things, been pre-occupied with finding alternative and less intrusive means of governance in recent years."1' The most important forms in which these new forms of governance manifest themselves are the increasing use of soft law instruments, selfregulation, co-regulation and delegating acts. Whereas soft law and delegating acts are well-established concepts, the concepts of self-regulation and co-regulation seem to have been granted different interpretations in literature and on the Union level. ${ }^{12}$ For practical reasons, I will confine myself to the view of the European decision-making institutions. Pursuant to Point 18 of the Interinstitutional Agreement on better law-making ${ }^{13}$, coregulation is "the mechanism whereby a [Union] legislative act entrusts the attainment of the objective defined by the legislative authority to parties which are recognised in the field [...]". In contrast, Point 22 sees self-regulation as "the possibility for [parties recognised in the field] to adopt amongst themselves and for themselves common guidelines at the European level". Hence, the difference between the two depends on whether or not a legislative act is involved. ${ }^{114}$ It does not depend on the direct involvement of a public authority, however; this can also be the case in self-regulation. ${ }^{115}$

The Commission announced its intention to foster self-regulation in European contract Law in its Action Plan shortly after the Millennium. In its Communication it particularly discussed the possibility of promoting the drafting of European-wide standard terms and conditions. ${ }^{116}$ Standardisation of contracts is in fact the most prominent function of selfregulation. It can occur directly by devising framework contracts or indirectly by either

111 Most notably: Communication from the Commission - Action plan "Simplifying and improving the regulatory environment", $\operatorname{COM(2002),~} 278$ final.

112 Senden 2005, at 3.1.

113 Interinstitutional Agreement on better law-making (2003/C 321/01).

114 Communication from the Commission - Action plan "Simplifying and improving the regulatory environment", $\operatorname{COM}(2002), 278$ final, p. 11.

115 As far as self-regulation is concerned, the Commission considers itself as a 'facilitator' of devising, say, standard terms and conditions on a European level: Cafaggi 2007, p. 8.

116 Communication from the Commission to the European Parliament and the Council: A more coherent European Contract Law - An Action Plan, COM(2003), 68, at. 81-88. 
contributing to the definition of contractual terms or the setting up of codes of conducts in specific sectors. ${ }^{17}$ It is interesting to note that by issuing such terms (in whatever way) the signatories or members of an association often regulate more than just their relationship vis-à-vis each other. Codes of conducts, for instance, might require firms to include certain clauses in agreements with third parties and in that way exert a regulatory influence on other parties. ${ }^{118} \mathrm{~A}$ good example is provided by the Code of Good Practice of the European Automobile Manufacturers' Association which has been enacted after the abolishment of the old Block Exemption Regulation for the car sector.119 It contains some of the rules which were previously part of the conditions for exemption, such as the obligation to provide for a minimum notice period of two years for all agreements of an indefinite period. Third parties (in this case, authorised distributors and repairers) are therefore affected by this Code. ${ }^{120}$

The question is to be raised why the Commission did hitherto not consider the possibility to become involved in the process of drafting Codes of Conducts for specific sectors. Of course, one of the reasons why the former Block Exemption Regulation for the car sector was abolished resulted from the fact that it was seen as intrusive for national contract law regimes. ${ }^{121}$ Yet all forms of standardisation, especially when they have an effect on third parties, always have to be scrutinised under the rules of competition. ${ }^{122}$ This in itself should suffice for the Commission to become involved when needed. Whether firms have to abide by a Block Exemption Regulation issued by the Commission, or by a Code of Conduct whose drafting process has been influenced by it, should not make a difference in terms of the mandate which the Commission enjoys in the area of competition policy. It was seen above that the Block Exemption Regulations generally function as they were loosely standardised cartel contracts. For firms it would therefore be desirable to become better involved in this standardisation process. The normative suggestion is that in some occasions it might be wise to shift the initiative to the private actors themselves while the Commission supervises the drafting process and either approves or disapproves the outcome ex post. Or, alternatively, the Commission could invite stakeholders to discuss the

117 Cafaggi 2007, p. 7.

118 Cafaggi 2007, p. 12.

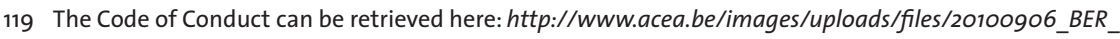
code_of_conduct.pdf.

120 See more generally on the Competition law issues in the car sector: Joerges 1985.

121 Clark \& Simon 2010, p. 481.

122 For a thorough analysis of the competition law issues in regards to standardisation, see: Dolmans 2002, p. 170 et seq. 
possibility of a binding Code of Conduct before issuing sector-specific rules for exemption. Also here, approval would eventually occur ex post.

\subsection{The Example of Sport Regulation}

The area of sports regulation constitutes an unorthodox example of where such a model could be tested. Since the Bosman ${ }^{123}$ ruling, the sports associations have had a difficult time coping with the unwanted (and unexpected) influence of EU law. But the practice of sport is not only subject to the rules of free movement, but also subject to European competition law. ${ }^{24}$ The problem for sports associations and clubs at the moment is that the legal framework governing their activities is regrettably unclear. ${ }^{25}$ So far the EU has approached the issue by combining soft law instruments with a case-by-case analysis of the CJEU. ${ }^{126}$ Whereas this indeed seems most appropriate for the Union, it is causing anything but certainty for stakeholders. ${ }^{127}$

The possibilities to overcome this state of affairs are varied, but only few of them seem realistic and/or fully adequate. Indeed, the most drastic step would be to call for Treaty amendments in order to once and for all clarify the status of sports in the Union; yet this idea seems as drastic as it is unrealistic in the current political climate. Another idea would be the issuing of further soft law instruments. However, only few will believe this genuinely solves the problem. Lastly, at least as far as Competition law is concerned, a Block Exemption Regulation seems to be in order on first sight. Also here some drawbacks can be identified: Most notably, due to the intertwinement of competition and free movement rules when it comes to sport regulation, a Block Exemption Regulation can never lead to a satisfactory result.

123 C-415/93 Union Royale Belge des Sociétés de Football Association ASBL v Jean-Marc Bosman, Royal Club Liégois SA v Jean-Marc Bosman [1995] ECR I-4921.

124 See for two recent cases: C-171/05 P Piau v Commission [2006] ECR I-37; C-519/04 P David Meca-Medina \& Igor Majcen v Commission [2006] ECR I-02549.

125 Vermeersch 2011.; This issue of the Journal of European Public Policy was completely dedicated to problems and policy questions of sport regulation in the European Union.

126 Most notably are the following: Declaration on the specific characteristics of sport and its social function in Europe, of which account should be taken in implementing common policies, annexed to the Conclusions of the Nice European Council, 7.-9. December, Bulletin EU 12-2000; Report from the European Commission to the European Council with a view to safeguarding current sports structures and maintaining the social function of sport within the Community framework ('The Helsinki Report on Sport'), $\operatorname{COM}(1999), 644$.

127 On the responses of sport associations to the problem, see: Garcia \& Weatherill, 2011. 
On the other hand, self-regulation or co-regulation could provide for an alternative. On self-regulation, the Commission could invite specific sport associations to set up Codes of Conduct which deal with issues of: "organising sports on a national level, the creation of new sporting organisations, club relocation, the ban on organising competition outside a given territory, the regulatory role of sporting event organisers, the transfer systems $[\ldots]$, nationality clauses, selection criteria [...], [...] ticket sales [...], broadcasting rights, sponsorship and the prohibition for clubs belonging to the one and the same owner to take part in the same competitions". ${ }^{128}$ The Code of Conduct devised in accordance with the rules governing the afore-mentioned aspects could then be approved ex post by the Commission and the latter would thereby agree not to initiate proceedings whenever rules are in line with it. Alternatively, specific sports associations could be vested with the power to regulate their profession in accordance with these aspects by virtue of a legislative act. Such act would then define the framework within which the associations have freedom of manoeuvre. In the case of sport activities, this even seems preferable given the intertwinement with the other rules on the free movement of persons. A possible legal basis for that could be found in Article 165(4) TFEU.

New forms of governance have started to play an increasingly important role in the European Union in general and in European contract law in particular; and private regulation is one the most significant examples of this trend. There is no good reason why this should not be continued, because the direct involvement of stakeholders both enhances legitimacy and does justice do a multi-level structure of the Union. ${ }^{129}$ The regulation of sport is only one example of an area with a competition law component. Whenever the Commission is contemplating the desirability of a sector-specific Block Exemption Regulation which only concerns a low number of undertakings, alternative forms of governance should be considered.

128 Commission debates the application of its rules to sports, IP/99/133, p. 3 .

129 To put it in the words of Micklitz, the question should always be "which norms shall be elaborated and enforced at what level and by whom": Micklitz 2008, p. 3. 


\section{Conclusions}

Due to the economisation of law, private law in the Union is increasingly regulatory. ${ }^{130}$ This allows competition law - which equally pursues a regulatory function - to influence the private law branch thanks to its constitutional status in the European legal order. The hypothesis that European private law can be shaped and directed from the boundaries of traditional private law and the the centre of European market law is therefore confirmed. It is hardly imaginable that this will only hold true for competition law; for also other 'core' areas of EU (economic) constitutional law, such as the law of free movement, or European equality law, may be expected to reveal similar results. ${ }^{131}$ This shows that there needs to be a more informed discussion on the sources of European private law.

It will be the task of mainly the CJEU and academia to identify the possibilities of cross-influences between the various branches in order to allow for a more coherent legal framework. This coherence is all the more required in light of the fragmentation of European private law as well as the hybrid nature of remedies. In the absence of farreaching Union power in the area of procedural law, regulation often works indirectly through the provision of general rules and principles. As far as the competition/private law interface is concerned, the rules on private enforcement constitute a perfect example for this peculiar feature of European market regulation.

Even more important, however, seems the certainty that new forms of governance lie at the heart of many recent developments in the area of private law. General decentralisation and the involvement of stakeholders in the law-making process may (somehow paradoxically) further the Europeanisation of private law. Whereas the Union remains the dominant policy-maker, private actors are given more responsibility in the process of setting up rules and their enforcement. Boldly speaking, this is a means to overcome lengthy political discourses between the EU and Member States. As Member States are, to a certain extent, taken out of the process, the Union directly acts grants the stakeholders involved greater power in regulating their respective field. On the one hand, this might indeed cause problems of legitimacy which need to be addressed. On the other hand, the multi-level structure of the Union calls for a rethinking of how regulation - particularly regulation of private legal relationships - should be done.

130 On the general shift in nature of private law, see: Cafaggi \& Watt 2009.

131 See e.g.: Rutgers 2008. 
Lastly, the discussion should have revealed that competition law plays a pivotal process in the afore-mentioned developments. As a result of its constitutional status, it exerts a noteworthy impact on other branches which have been treated as completely distinct in the past. Where formerly only the tensions between, for instance, contract and competition law have been focused upon, there is now a rising awareness that the latter might play a more and more complementary role as well. And this role is not only to restrict parties in their freedom to contract, but to vest them with rights against misconduct of other market participants, including co-contractors. In this sense, it would be interesting to scrutinise in what way the influence of competition law relates to the relationship between contract and tort law in general.

It is to be hoped that the acquis group, in drafting new instruments, will take a greater account of the role of competition law in regulatory private law. But also the Commission, most notably when enacting new Block Exemption Regulations, should have due regard to the impact these measures have on private parties. After all, it has been seen that these Regulations can equally be considered as contractual rules insofar as they standardise cartel agreements. My claim therefore reads that a more thorough investigation needs to be conducted what aspects of private legal relations are influenced by such new instruments and how. These considerations have hitherto been completely absent at least as far as the Commission is concerned. 


\section{Bibliography}

\section{Secondary Sources:}

Albert-Llorens 2006

- Albertina Albert-Llorens; 'Consumer Law, Competition Law and the Europeanization of Private Law', in: G. de Burca et al., (Eds.); The Institutional Framework of Private Law. Oxford [etc.]: Oxford University Press, 2006

Amato 2009

- Giuliano Amato; Antitrust and the Bounds of Power. Oxford: Hart Publishing, 1997

Cafaggi 2007

- Fabrizio Cafaggi, 'Self-Regulation in European Contract Law'. European Journal of Legal Studies 1, 2007

Cauffman 2013

- Caroline Cauffman, 'The impact of voidness for infringement of Article 101 TFEU on linked contracts'. Maastricht European Private Law Institute Working Paper No. 2013/3

\section{Cafaggi \& Watt 2009}

- Fabrizio Cafaggi \& Horatia Muir Watt; The Regulatory Function of European Private Law. Cheltenham [etc.]: Edward Elgar Publishing, 2009

Collins 2011

- Hugh Collins; 'The Hybrid Quality of European Private Law', in: Brownsword et al., (Eds.); The Foundations of European Private Law. Oxford: Hart Publishing, 2011

Cruz 2002

- Julio Baquero Cruz; Between Competition and Free Movement. Oxford: Hart Publishing, 2002

Clark \& Simon 2010

- John Clark \& Stephan Simon, 'The New Legal Framework for Motor Vehicle Distribution: A Toolkit to Deal with Real Competition Breakdowns'. Journal of European Competition Law \& Practice 1 (6), 2010

\section{Cseres 2005}

- Katalin Judit Cseres, Competition Law and Consumer Protection. The Hague: Kluwer Law International, 2005

Cseres 2010

- K. Cseres, 'Competition and Contract Law', in: A. Hartkamp et al., (Eds.); Towards a European Civil Code. $4^{\text {th }}$ edition, The Hague: Kluwer Law International, 2010 


\section{Cseres 2010}

- Katalin Judit Cseres, 'Comparing Laws in the Enforcement of EU and National Competition Laws'. European Journal of Legal Studies 3 (1), 2010

Dolmans 2002

- Maurits Dolmans, 'Standards for Standards'. Fordham International Law Journal 26 (1), 2002

Dreifuss-Netter 1990

- Frédérique Dreifuss-Netter, 'Droit de la Concurrence et Droit Commun des Obligations'. Dalloz 3, 1990

Ehlermann 2000

- Claus D. Ehlermann, 'The Modernization of EC Antitrust Policy: A Legal and Cultural Revolution'. European Competition Law Review 17 (2), 2000

Evans \& Quigley 2000

- Lewis T. Evans \& Neil C. Quigley, 'Contracting, Incentives for Breach, and the Impact of Competition Law'. World Competition 23 (2), 2000

Garcia \& Weatherill 2011

- Borja Garcia \& Stephen Weatherill, 'Engaging with the EU in order to minimize its impact: sport and the negotiation of the Treaty of Lisbon'. Journal of European Public Policy 3 (3), 2011 Grundmann 1999

- Stefan Grundmann; Europäisches Schuldvertragsrecht - Das europäische Recht der Unternehmensgeschäfte. Berlin: De Gruyter, 1999

Jones \& Sufrin 2011

- Alison Jones \& Brenda Sufrin; EU Competiton Law - Text, Cases, and Materials, $4^{\text {th }}$ edition, Oxford [etc.]: Oxford University Press, 2011

Joerges 1985

- Christian Joerges, 'Relational Contract Theory in a Comparative Perspective: Tensions Between Contract and Antitrust Law Principles in the Assessement of Contract Relations Between Automobile Manufacturers and Their Dealers in Germany'. Wisconsin Law Review, 1985,

Joerges 2000

- Christian Joerges, "Transnationale "deliberative Demokratie" oder "deliberativer Supranationalismus"? Anm. Zur Konzeptualisierung legitimen Regierens jenseits des Nationalstaats bei Rainer Schmalz-Bruns'. Zeitschrift für Internationale Beziehungen 7, 2000 Kelemen 2011

- R. Daniel Kelemen; Eurolegalism - The Transformation of Law and Regulation in the European Union. Cambride [etc.]: Harvard University Press, 2011 
Mak 2009

- Vanessa Mak, 'A Shift in Focus: Systematisation in European Private Law Through EU Law'. Tilburg Institute of Comparative and Transnational Law Working Paper No. 2009/12

Maher 2004

- Imelda Maher; 'Regulating Competition', in: C. Parker et al., (Eds.), Regulating Law. Oxford [etc.]: Oxford University Press, 2004

Mestmäcker 2008

- Ernst-Joachim Mestmäcker, 'A Legal Theory without Law: Posner v. Hayek on Economic Analysis in Law'. Max Planck Institute for Comparative and International Private Law Working Paper, 2008

Micklitz 2008

- Hans-W.Micklitz,'TheVisible Hand of European Regulatory Private Law:TheTransformation of European Private Law from Autonomy to Functionalism in Competition and Regulation'. European University Institute Working Paper Law No. 2008/14

Parret 2011

- Laura Parret; Side effects of the modernisation of EU competition law-Modernisation as a challenge to the enforcement system of EU competition law and EU law in general. Nijmege. Wolf Legal Publishers, 2011

\section{Reich 2005}

- Norbert Reich, 'The “Courage” Doctrine: encouraging or discouraging compensation for antitrust Injuries?'. Common Market Law Review 42 (35), 2005

Reich 2007

- Norbert Reich,'Horizontal Liability in EC Law: Hybridisation of Remedies for Compensation in Case of Breaches of EC Rights'. Common Market Law Review 44, 2007

Riley 2003

- Alan Riley, 'EC Antitrust Modernisation: The Commission Does Very Nicely - Thank You! Between the Idea and the Reality: Decentralisation under Regulation 1'. European Competition Law Review 24, 2003

Rutgers 2008

- Jacobien W. Rutgers, 'Free Movements and Contract Law'. European Review of Contract Law 4 (3), 2008

Schillig 2008

- Michael Schillig,'Inequality of bargaining power versus market for lemons: legal paradigm change and the Court of Justice's jurisprudence on Directive 93/13 on unfair contract terms'. European Law Review 33, 2008 


\section{Schurr 2008}

- Francesco A. Schurr, 'What Role Does Competition Law Play in the Genesis of a Harmonised European Private Law'. Revue Juridique Polynésienne 14, 2008

\section{Senden 2005}

- Linda Senden, 'Soft Law, Self-Regulation and Co-Regulation in European Law: Where Do They Meet?'. Electronic Journal of Comparative Law 9 (1), 2005

\section{Stuyck 2005}

- Jules Stuyck, 'Case: ECJ - Courage v Crehan', European Review of Contract Law 1 (2). 2005

De Smijter \& Kjoelbye 1999

- Eddy de Smijter \& Lars Kjoelbye; 'The Enforcement System under Regulation 1/2003', in: Jonathan Faull \& Ali Nikpay, (Eds.); The EC Law of Competition. Oxford [etc.]: Oxford University Press, 1999

\section{Snyder 2000}

- Francis Snyder; The Europeanisation of Law: The Legal Effects of European Integration. Oxford: Hart Publishing, 2000

\section{Steiner 2007}

- Mark Steiner; Economics in Antitrust Policy: Freedom to Compete vs. Freedom to Contract. Dissertation.com, 2007

\section{Tridimas 2006}

- Takis Tridimas; The General Principles of EU Law. $2^{\text {nd }}$ edition, Oxford: Oxford EC Law Library, 2006

\section{Ullrich 2005}

- Hanns Ullrich, 'Anti-Unfair Competition Law and Anti-Trust Law: A Continental Conundrum?'. European University Institute Working Paper Law No. 2005/01

Vermeersch 2011

- An Vermeersch, 'All's fair in Sport and Competition? The Application of EC Competition Rules to Sport'. Journal of European Public Policy 3 (3), 2011

Vogelaar 2002

- Floris O. W. Vogelaar, 'Modernisation of EC competition law - Economy and horizontal cooperation between undertakings'. Intereconomics 37 (1), 2002

Wesseling 2000

- Rein Wesseling; The Modernisation of EC Antitrust Law. Oxford: Hart Publishing, 2000 Wigger 2004

- Angela Wigger, 'Revisiting the European Competition Reform: The Toll of Private SelfEnforcement', University of Amsterdam Working Papers Political Science No. 2004/07 


\section{Wigger 2007}

- Angela Wigger; 'Towards a Market-Based Approach: The Privatization and MicroEconomization of EU Antitrust Enforcement', in: Henk Overbeck et al., (Eds.); The Transnational Politics of Corporate Governance Regulation. Oxford [etc.]: Routledge Chapman \& Hall, 2007

Wilks 2005

- Stephen Wilks, 'Agency Escape: Decentralization or Dominance of the European Commission in the Modernization of Competition Policy?', Governance 18 (3), 2005

Wijckmans \& Tuytschaever 2011

- Frank Wijckmans \& Filip Tuytschaever; Vertical Agreements in EU Competition Law. $2^{\text {nd }}$ edition, Oxford [etc.]: Oxford University Press, 2011

Wilks 2005

- Stephen Wilks; 'Competition Policy: Challenge and Reform', in: Helen Wallace et al., (Eds.); Policy-Making in the European Union. Oxford [etc.]: Oxford University Press, 2005

Wouters 2012

- Jan Wouters; 'Private law, global governance and the European Union', in: Anne L. M. Keirse \& Marco B. M. Loos, (Eds.); Alternative Ways to lus Commune - The Europeanisation of Private Law. Antwerp: Intersentia, 2012

\section{Van Gerven 2000}

- Walter van Gerven, 'Of Rights, Remedies and Procedures'. Common Market Law Review 37, 2000

\section{Van Gerven 2003}

- Walter van Gerven;'Substantive Remedies for the Private Enforcement of EC Antitrust Rules Before National Courts', in: C.D. Ehlermann \& I. Atanasiu, (Eds.); European Competition Law Annual 2001: Effective Private Enforcement of EC Antitrust Law. The Hague: Hart Publishing, 2003

Van Gerven 2006

- Walter van Gerven, 'Bringing (Private) Laws Closer to Each Other at the European Level', in: Fabrizio Cafaggi, (Eds.); The Institutional Framework of European Private Law - Volume XV/2, Oxford [etc.]: Oxford University Press, 2006 